\title{
Analysis of marine macrobenthic community structure in relation to pollution, natural oil seepage and seasonal disturbance in a tropical environment (Trinidad, West Indies)
}

\author{
J. B. R. Agard ${ }^{1}$, J. Gobin ${ }^{1,2,3}$, R. M. Warwick ${ }^{3}$ \\ ${ }^{1}$ Department of Zoology, University of the West Indies, St. Augustine, Trinidad and Tobago, West Indies \\ ${ }^{2}$ Institute of Marine Affairs, PO Box 3160, Carenage, Trinidad and Tobago, West Indies \\ ${ }^{3}$ Plymouth Marine Laboratory, Prospect Place, The Hoe, Plymouth PL1 3DH, United Kingdom
}

\begin{abstract}
Macrobenthic species abundances and biomasses were determined at 31 stations from Pointe-à-Pierre to La Brea, Trinidad. This area is subject to chronic natural oil seepage and spillage from oil production activities. Multivariate analysis was used to define those environmental variables which best explained community composition. The deeper sites were impoverished due to the development of anoxia below a pycnocline which formed during the wet season. Abundance/biomass comparison $(\mathrm{ABC})$ plots indicated that macrobenthic communities near an oil refinery were grossly to moderately stressed while those close to the Trinidad Pitch Lake, one of the largest natural oil seeps in the world, were not. Taxonomic aggregation of the species data to family level resulted in little loss of information in the multivariate analyses and apparently improved the ability of $A B C$ curves to discriminate pollution. Comparisons of the severity of community degradation at these sites using a phylum-level meta-analysis of 'production' were compatible with NE Atlantic data, which augurs well for the more global applicability of this approach. A feature of the Trinidad samples is that they all separate along the upper edge of the meta-analysis 'wedge', due mainly to their higher average proportion of Crustacea relative to Echinodermata and Mollusca. This is explained in terms of the estuarine character of the region, and suggests that the unexplained vertical axis in Warwick \& Clarke's (companion article) ordination may be related to natural environmental characteristics.
\end{abstract}

\section{INTRODUCTION}

One of the challenges of the benthic community approach to pollution monitoring is to develop a suite of objective analytical protocols which are easy to apply and accessible to laboratories with less sophisticated resources. Comparison of several appropriate methods which may fit these criteria (Gray et al. 1988) shows that they give essentially the same results for a strong pollution gradient (Warwick 1988c). Further, there is little if any loss of information if the data are analysed at higher taxonomic levels (Warwick 1988a, b, Ferraro \& Cole 1990), and phylum-level analysis may permit comparative studies of the severity of pollution effects from physically dissimilar and geographically distant areas (Warwick \& Clarke 1993). These findings may be help- ful in many areas of the tropics where the taxonomy of the benthic fauna is not well-known or well-documented. However, the question remains as to whether such techniques are directly applicable to these areas. In particular, the phylum-level meta-analysis approach has only been applied to NE Atlantic sites. Since it depends on a predictable phyletic composition in unperturbed situations and also on predictable changes in this composition with increasing levels of perturbation, its validity for use on a more global scale needs testing. Here we have done this in a tropical setting where natural and man-induced perturbations are many and varied. Firstly, we have assessed the level of community degradation at each station by a variety of conventional means, and then compared this scaling with that from NE Atlantic samples. An additionally interesting aspect 
of this study is that chemical inputs in the study area occur on both ecological and evolutionary time scales in close proximity.

The study was initiated in the Pointe-à-Pierre to La Brea region on the island of Trinidad, West Indies. This area is a large coastal embayment opening into the semi-enclosed Gulf of Paria between Trinidad and the Venezuelan mainland. Marine conditions are estuarine and seasonal. Contamination occurs here on what is probably an evolutionary time scale from one of the world's largest hydrocarbon seeps at La Brea, Trinidad (Wilson et al. 1974, Geyer \& Giammona 1980). This is contrasted with contamination over ecological time from an oil refinery at Pointe-à-Pierre a few kilometers away (Agard et al. 1988), Rivers along the coast also bring sewage and trace metal contamination from the city of San Fernando. Observations near the La Brea oil
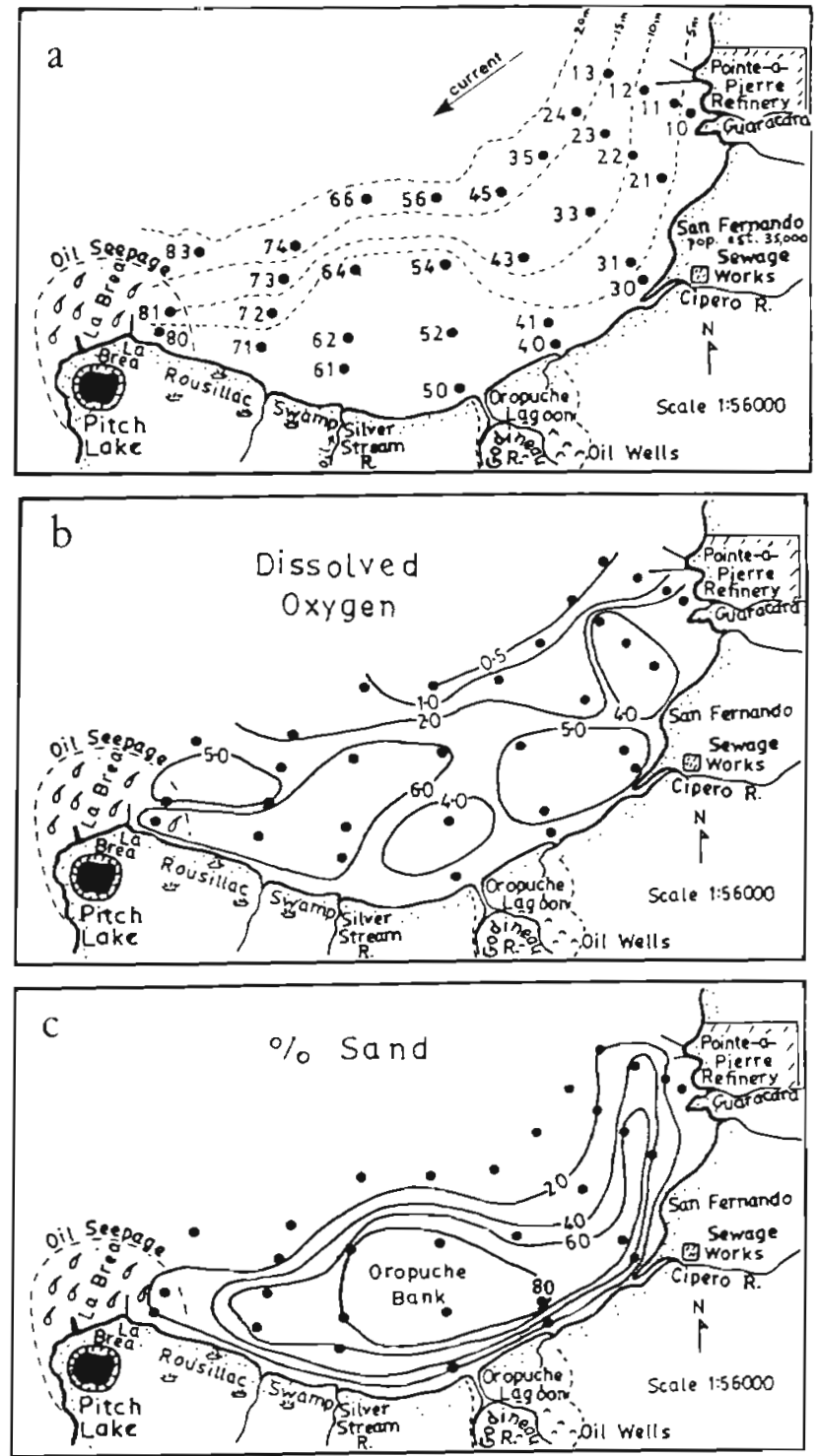

seep record a diverse benthic macrofauna (Government of Trinidad and Tobago 1984), which may rely on hydrocarbon-degrading bacteria as a food source (ZoBell \& Feltham 1938). It is hypothesised that multivariate and univariate measures of disturbance should therefore indicate pollution near the oil refinery due to the episodic and varied nature of the discharges, with synergistic effects due to contaminants other than oil, but not near the oil seep.

\section{METHODS}

Stations were sited along transects originating from prominent landmarks on shore (Fig. 1a). In the field, 6 van Veen grab samples $\left(0.04 \mathrm{~m}^{2}\right.$ each) were taken at each of 31 stations (Fig. 1a) between 8 and 17 March
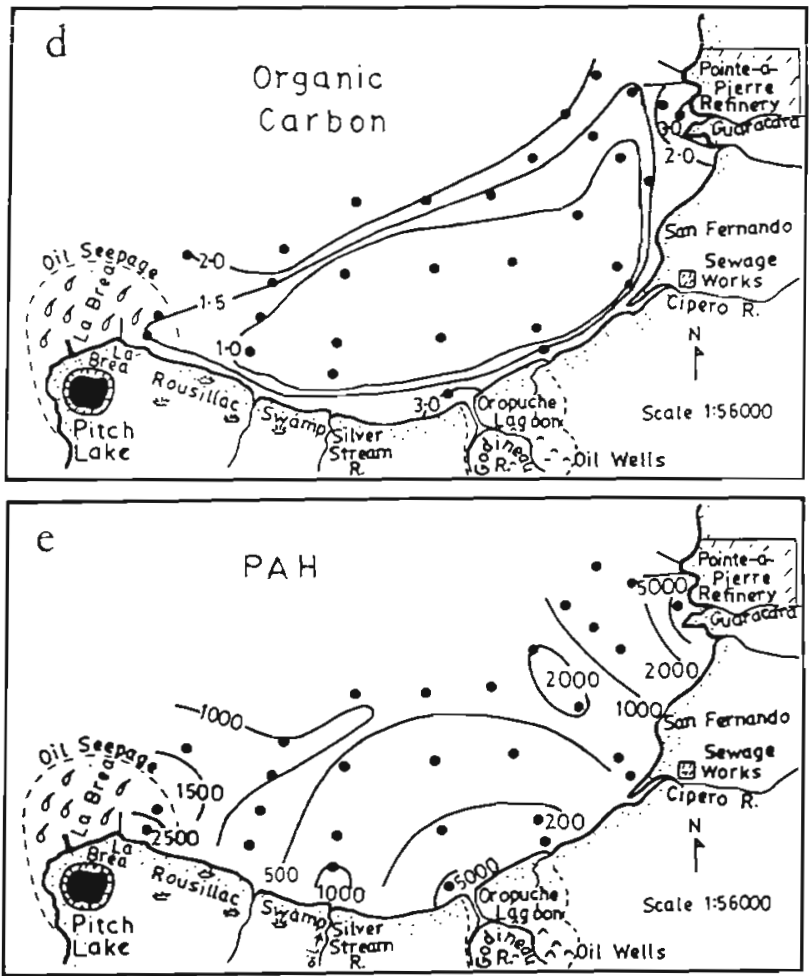

Fig. 1 (a) Pointe-à-Pierre to La Brea embayment, showing sampling station positions. Bathymetric contours: 5, 10, 15 and $20 \mathrm{~m}$. (b) Oxygen concentration $\left(\mathrm{mg} \mathrm{l}^{-1}\right.$ ) in bottom waters. showing oxygen depletion $\left(<2 \mathrm{mg} \mathrm{l}^{-1}\right)$ off the San Fernando coast. (c) Distribution of \% sand in sediments. (d) Distribution of $\%$ organic carbon in sediments. (e) Distribution of total polyaromatic hydrocarbons $\left(\mu \mathrm{g} \mathrm{g}^{-1}\right.$ dry wt Kuwait crude oil equivalents) in sediments 
1983 during the dry season and again during the wet season 24 to 30 August 1983. Five of the replicates were sieved at $0.5 \mathrm{~mm}$, stained with Rose Bengal and preserved in formalin. Subsamples from the top $5 \mathrm{~cm}$ of the sixth grab were frozen until laboratory analysis for physico-chemical variables (see below). Temperature, salinity and dissolved oxygen measurements were also taken near $(<10 \mathrm{~cm})$ the bottom at each station.

In the laboratory the macrofauna were sorted, identified to species level where possible, counted, blotted to remove excess formalin and weighed (molluscs without shells). Trace metal concentrations in sediments were determined by atomic absorption spectrophotometry after extraction in $0.5 \mathrm{M}$ hydrochloric acid, total polycyclic aromatic hydrocarbon residues by UVfluorescence (International Oceanographic Commission 1982), total organic carbon by chromic acid oxidation and sediment granulometry by wet sieving.

Similarity of species compositions between stations was determined by non-metric multi-dimensional scaling (MDS) (Kruskal \& Wish 1978) ordination using the square root transformed pooled data from the replicates at each station with the Bray-Curtis similarity index (Clarke \& Green 1988). Differences between sites were determined using the ANOSIM randomisation/permutation test (Clarke 1988). To assess which combination of environmental variables best related to the biotic data for the dry and wet seasons the protocols given by Clarke \& Ainsworth (1993) were followed, using the computer program BIOENV. Symbols scaled in size to represent the values of environmental variables were also individually superimposed onto the faunistic 2-dimensional MDS configurations in order to identify obvious visual concordance (Field et al. 1982). For both seasons, species data were aggregated into phyla, combined to produce 'production' matrices $\left[(B / A)^{0.73} \times A\right.$, where $A=$ abundance and $B=$ biomass] and merged with the 50 standard sites used by Warwick \& Clarke (1993) in their meta-analysis of NE Atlantic macrobenthos. The meta-analysis was then performed using this expanded data set. Abundance/biomass comparison (ABC) curves (Warwick 1986, Clarke 1990) were used to assess the degree of disturbance at each station.

\section{RESULTS}

\section{Environmental conditions}

There was very little spatial or seasonal change in water temperature with a dry season mean of $26.8^{\circ} \mathrm{C}$ and a wet season mean of $27.3^{\circ} \mathrm{C}$. During the dry season salinity was relatively constant with a mean of $32.4 \%$. This showed a decrease to $26.9 \%$ during the wet season. Salinities at the deeper stations however remained virtually unchanged with values $>31 \%$, indicating the formation of a pycnocline. During the dry season, bottom dissolved oxygen was $>4 \mathrm{mg} \mathrm{l}^{-1}$ at all stations except for river mouths. In the wet season, superimposed on this pattern was the development of an area of depleted oxygen $\left(<2 \mathrm{mg} \mathrm{l}^{-1}\right)$ at the deeper stations (Fig. 1b). Sediment particle-size distribution. during the dry season is summarised in Fig. 1c as $\%$ sand. The most prominent feature of the area is a large sandy shoal (locally called the Oropuche Bank) bounded on its landward and seaward edges by muddy sediments. During the wet season this pattern remained essentially unchanged (diagram not shown here). Organic carbon distribution in sediments in the dry season is shown in Fig. 1d, and is essentially unchanged in the wet season. Organic content generally tended to increase offshore, with localised accumulations at river mouths. Fig. 1e shows that there are substantial gradients of polycyclic aromatic hydrocarbon (PAH) residues extending from the vicinity of both the Guaracara River (on which the oil refinery is situated) and the asphalt (pitch) lake during the dry season. This pattern was the same in the wet season.

\section{Faunistic ordinations}

In a total of 310 grab samples $\left(0.04 \mathrm{~m}^{2}\right.$ each), there were 25129 organisms of 204 species. Twodimensional MDS configuration solutions for abundances and biomasses of the organisms found during the dry and wet seasons are displayed in Fig. 2. In both seasons the abundance and biomass configurations are very similar. In the dry season the tight cluster of stations to the upper left of the configuration corresponds to sandy areas of the Oropuche Bank. At the bottom of the configuration 5 stations $(10,11,30,40$ $\& 50$ ) are those closest to known pollution sources. The remaining right-hand group comprises the offshore muddy stations. In the wet season the pattern is essentially similar except that 2 stations from the inshore group (Stns 11 \& 30) now cluster with the offshore 'Oropuche Bank' group and 5 of the extreme offshore stations $(12,13,24,45 \& 56)$, which are subjected to anoxia in this season, now cluster with the lower group of inshore stations $(10,40 \& 50)$.

\section{Relationships with environmental variables}

The environmental variables included in the correlation analysis were petroleum hydrocarbons, organic carbon, percent sand, water depth, dissolved oxygen, lead, copper and salinity. Complete data for all variables 
were not available for 3 stations in the dry season (Stns 21, $23 \& 43$ ) and 2 stations in the wet season (Stns $12 \& 66$ ): these were omitted from the analysis. Pairwise scatter-plots between all combinations of environmental variables for both seasons suggested a $\log (1+x)$ transformation of $\mathrm{PAH}, \mathrm{Pb}$ and $\mathrm{Cu}$, and for the dry season a reverse logarithmic transformation for salinity $[\log (36-S)]$ (K. R. Clarke pers. comm.). There were no correlations between environmental variables above a value of 0.9 , and so all variables were included in the BIOENV analysis. The weighted Spearman rank correlation coefficient between the similarity matrix underlying the faunistic MDS and the Euclidean distance matrices underlying the PCAs for all combinations of environmental variables (Clarke \& Ainsworth 1993) showed that for the dry season the combination of variables which had the maximum correlation with the macrobenthic abundance and biomass data was water depth and sediment lead concentration $(\rho=0.48$ for macrobenthic abundance and 0.43 for biomass). For the wet season the optimum combination for environmental variables was organic carbon, water depth and dissolved oxygen ( $\rho=0.52$ for abundance and 0.50 for biomass). These correlations were quite low in comparison with other examples given in Clarke \& Ainsworth (1993), indicating that the set of environmental variables considered has a rather weak explanatory power. It is

(a) DRY SEASON ABUNDANCE

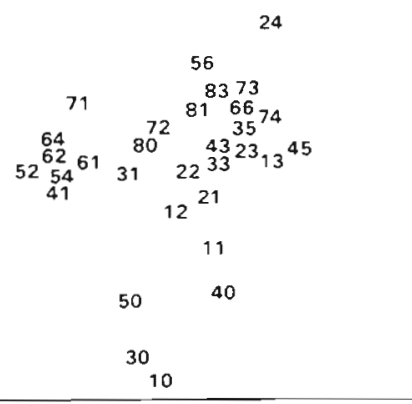

(c) WET SEASON ABUNDANCE

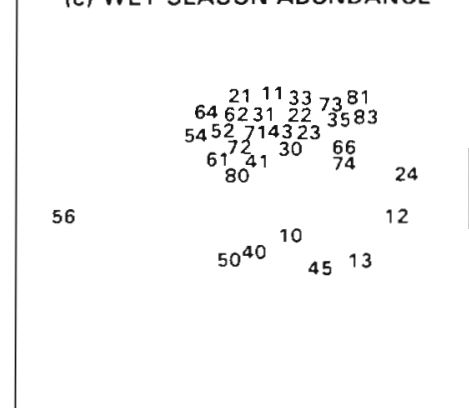

Fig. 2. MDS configurations by station for macrofauna species: (a) dry season abundance; (b) dry season biomass; (c) wet season abundance; (d) wet season biomass unfortunate that, in all but one case, the missing data were for petroleum hydrocarbon concentrations in the sediment, and the stations which had to be omitted from the analysis were mainly close to the oil refinery where extremely high values would have been expected.

The variables which individually correlated well with the faunistic data are superimposed on the species abundance ordinations in Figs. 3 (dry season) and 4 (wet season). In the dry season water depth decreases from the top right to bottom left of the configuration, while organic carbon and copper decrease towards the top left. In the wet season (ignoring Stn 56 to the extreme left of the configuration which was represented by only 1 species), water depth increases from left to right, organic carbon decreases towards the top left, while \% sand and dissolved oxygen concentrations are lowest towards the bottom right.

\section{Abundance/biomass comparison}

Fig. 5 shows the $A B C$ curves for each station in the dry season. Stns 10,30 \& 50 exhibit what Warwick (1986) defines as the 'grossly disturbed' configuration with the abundance curve above the biomass curve throughout its length. Stns $21 \& 71$ according to the criteria of Clarke (1990) display the 'moderately/grossly disturbed' configuration with the abundance curve dominating the biomass curve for most of its length except for rarer species. Stns 11 \& 54 are of the 'moderately disturbed' type with the abundance and biomass curves crossing. Stns $12,35,64 \& 83$ are classified as 'moderately/undisturbed' since in each case the biomass curve is above the abundance curve for almost all of its length except for a single species. The fauna of Stns $24,45,56$, $66 \& 74$ is impoverished, with individual species biomasses all below the accuracy of the scale used (1 $\mathrm{mg}$ ), so that no direct interpretation of the $A B C$ curves is attempted. All other sites show the 'undisturbed' condition with the biomass curve above the numbers curve for its entire length. Fig. 6a summarises these relationships as a map of the sampling sites with their degree of disturbance as derived from the $\mathrm{ABC}$ curves superimposed. It shows an area of disturbed benthos originating near the mouth of the Guaracara River and extending for about $5 \mathrm{~km}$ offshore. There is also an area of impoverished fauna or disturbance in deeper waters along the edge of the Oropuche Bank. A few other localised areas of disturbed benthos occur near the Cipero, Godineau, and Rousillac river 

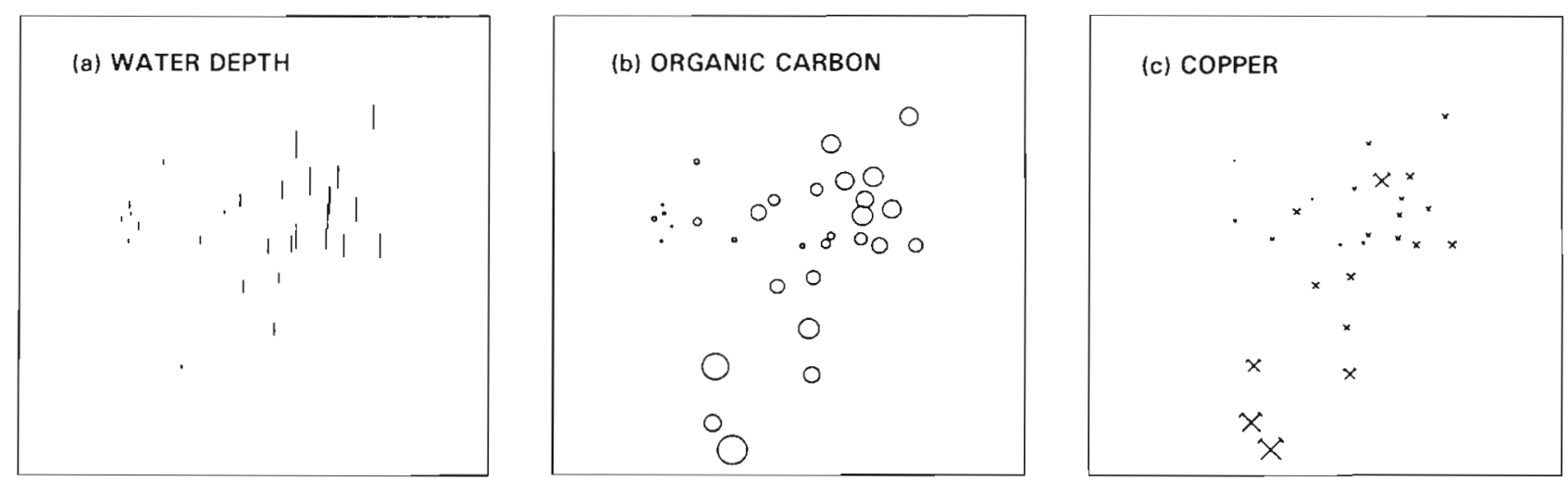

Fig. 3. MDS of the dry season species abundance as in Fig. 2a with superimposed symbols proportional to the values of the key environmental variables at these sites (range in parentheses). (a) Water depth (0.5 to $17.8 \mathrm{~m})$; (b) \% organic carbon (0.2 to $3.2 \%$ ); (c) copper $\left(0.9\right.$ to $\left.35.5 \mathrm{mg} \mathrm{g}^{-1}\right)$

mouths. No such disturbance is evident near the Pitch Lake. In the wet season the pattern is similar, except that the inshore Stns 10 \& 11 close to the oil refinery show the unpolluted $\mathrm{ABC}$ condition (Fig. 6b). turbed benthos offshore of the asphalt lake is also slightly extended. In the wet season the impoverished offshore area is also extended, as there is a distinct area of disturbance emanating from the mouth of the Godineau River where the highest hydrocarbon levels (>5000 $\mathrm{Mg} \mathrm{g}^{-1}$ dry wt at Stn 50) recorded in this study were found (Fig. 8b).

\section{Taxonomic reductions}

The macrofauna data were aggregated to families and the MDS and $A B C$ analyses re-run. As found previously in other studies (Warwick 1988a, b), the MDS configurations for abundance and biomass in both dry and wet seasons were very similar to the species level ordinations, and are not presented here. Similarly most of the $A B C$ plots for the macrofauna at family level gave essentially the same results as the species plots (Fig. 7). In the dry season, differences occurred for Stns 13, 23, 35 \& 66 which had too few families $(<3)$ to plot acceptable graphs and were interpreted as impoverished. Stns 22, 31, $33 \& 41$ previously displayed the undisturbed condition but now show moderate/undisturbed, moderate, moderate and gross/moderate disturbance, and Stn 83 changed from moderate/undisturbed to undisturbed. These changes, when compared with Fig. 6a, extend the area of impoverished fauna at the deeper stations as well as the offshore area of moderately disturbed benthos between the Guaracara and Cipero rivers (Fig. 8a). The area of undis-
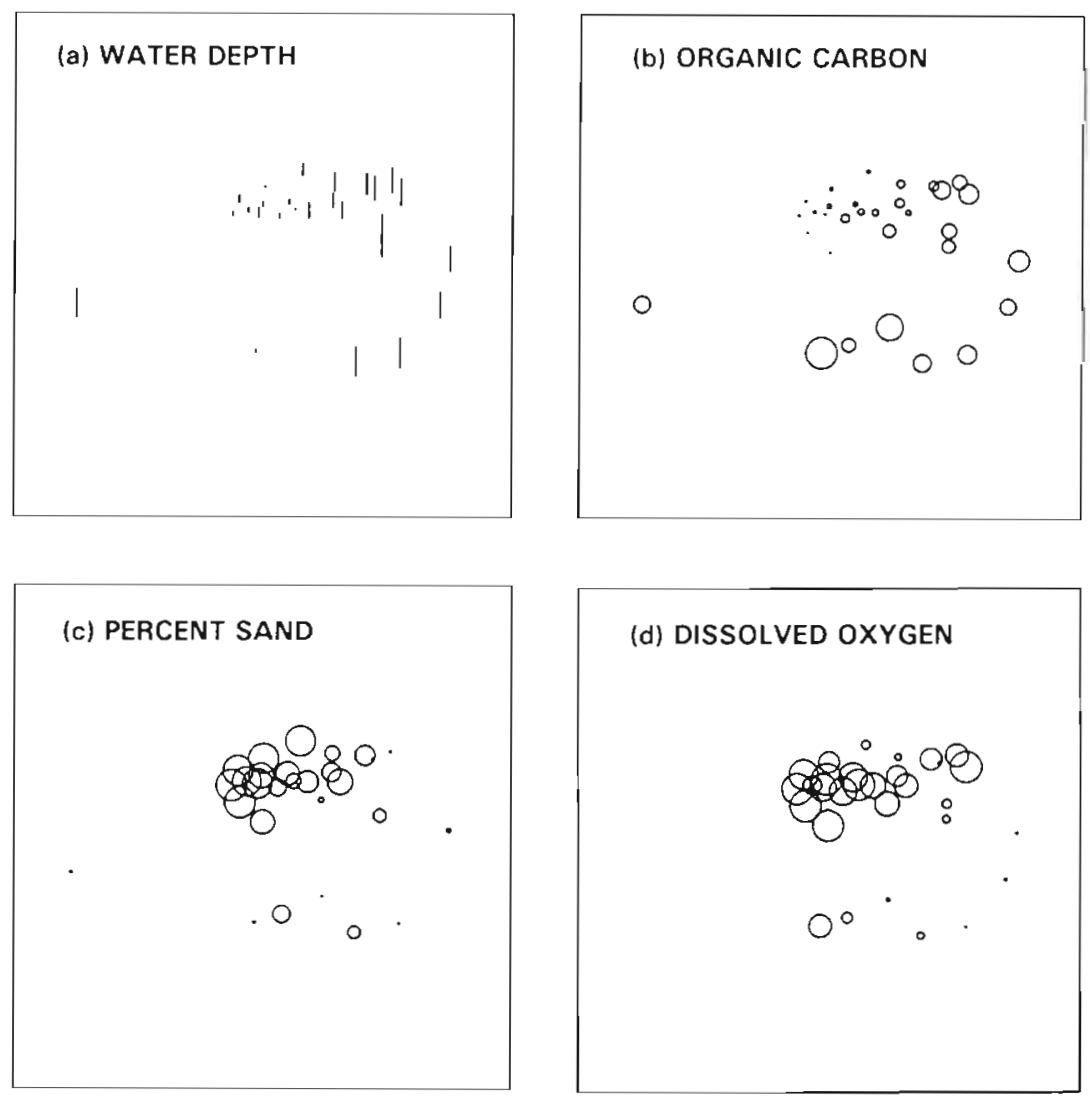

Fig. 4. MDS of the wet season species abundance as in Fig. 2c with superimposed symbols proportional to the values of the key environmental variables at these sites (range in parentheses). (a) Water depth (0.5 to $20.6 \mathrm{~m}$ ); (b) \% organic carbon $(0.1$ to $4.0 \%)$; (c) \% sand $(3.0$ to $97.7 \%)$; (d) dissolved oxygen $\left(0.1\right.$ to $\left.6.5 \mathrm{mg} \mathrm{l}^{-1}\right)$ 


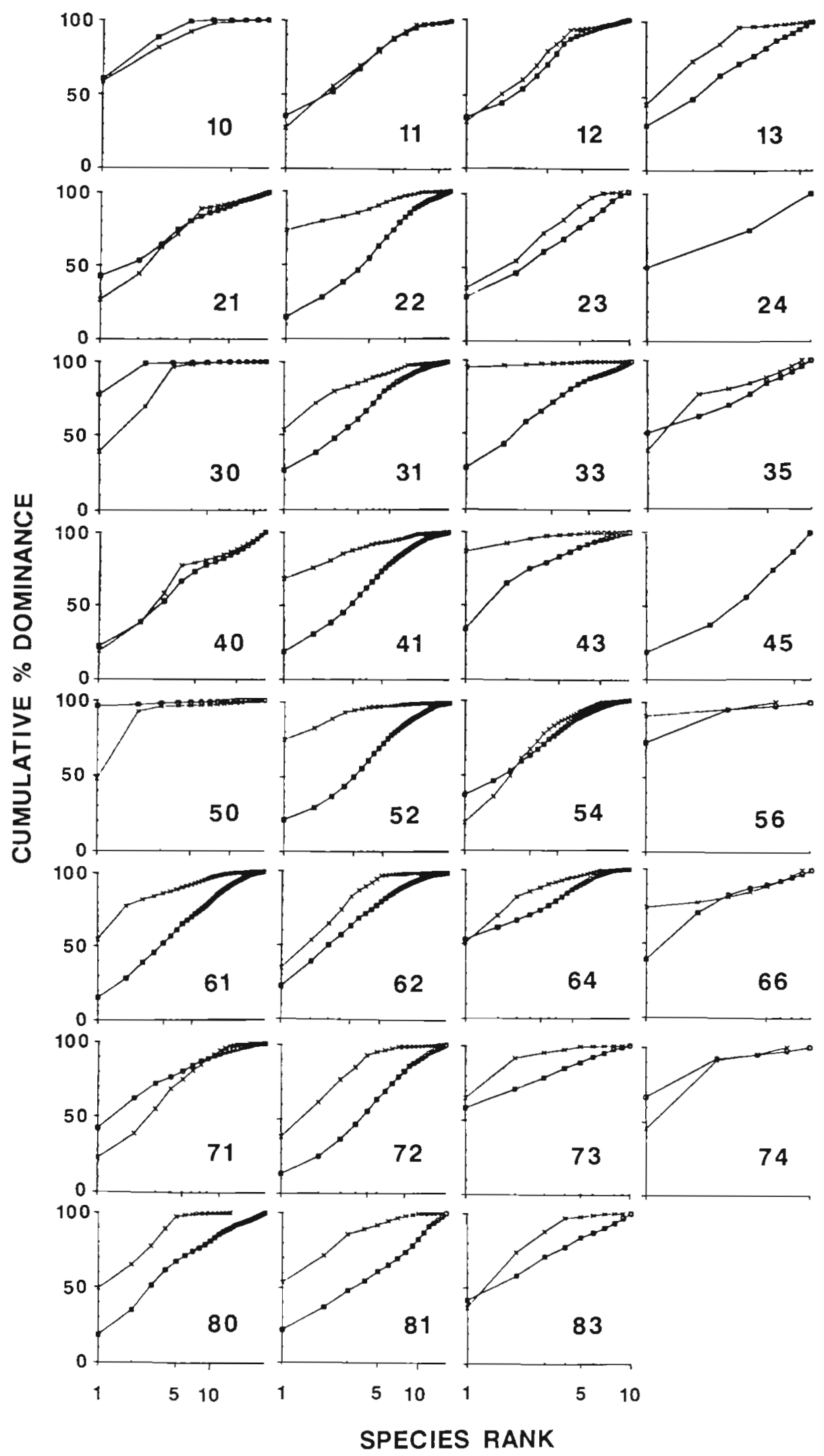

Fig. 5. ABC curves for dry season macrofauna species. ( 1 ) Abundance; ( $x$ ) biomass 

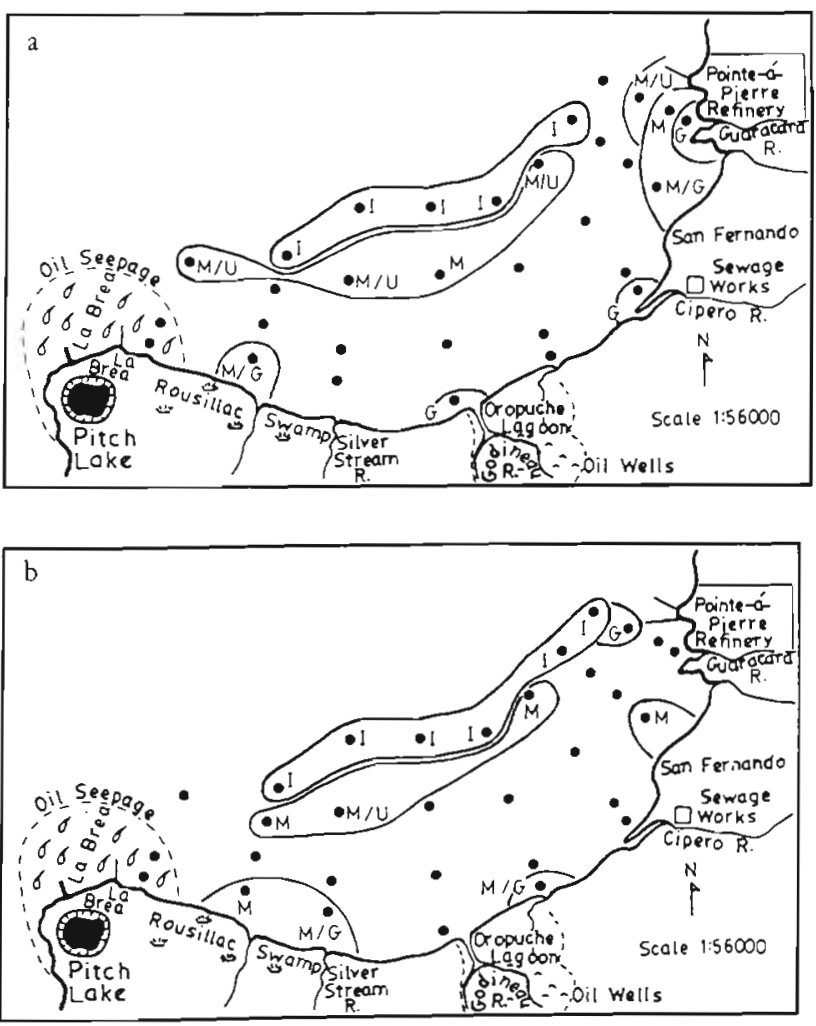

Fig. 6. Pointe-à-Pierre to La Brea area showing the degree of macrofaunal disturbance at each site during the dry (a) and wet (b) seasons as derived from the $A B C$ curves. G: gross; $M$ : moderate; U or no symbol: undisturbed: I: impoverished fauna

\section{Phylum-level meta-analysis}

Impoverished stations (with less than 5 species) were omitted from this analysis. The results (Fig. 9) are presented in 2 forms, firstly with all stations identified and secondly with the standard 50 stations of Warwick \& Clarke (1993) represented as dots so that the relative positions of the Trindad stations can be clearly seen. In both seasons the Trinidad stations span almost the entire range of the long axis of the standard 'wedge', suggesting that on a global scale some of the stations are severely polluted, although none are as grossly disturbed as those at the centre of the Garroch Head (Scotland) sewage-sludge dump-site, C6 and C7 (Pearson 1987), at the extreme right. In the dry season Stns $10 \& 11$, closest to the oil refinery, are at the righthand (most disturbed) end of the configuration, and the Oropuche Bank stations are at the left-hand (undisturbed) end, with the remaining stations showing intermediate levels of disturbance. In the wet season, Stns $10 \& 11$ have moved in the undisturbed direction, the latter appearing to be the least disturbed of all stations. The most disturbed station (50) is closest to the outflow of the Godineau River. The split between the undisturbed Oropuche Bank stations and the remaining moderately disturbed stations is still evident, as in the dry season.

Another feature of both seasons is that the Trinidad stations are all clustered along the upper edge of the wedge. An analysis of the contribution of each phylum to the average Bray-Curtis dissimilarity between all the Trinidad samples and all the NE Atlantic samples, using the computer program SIMPER (Clarke 1993), shows that this is due mainly to the higher average proportion of Crustacea and lower proportion of Echinodermata and Mollusca in the Trinidad samples (Table 1).

\section{DISCUSSION AND CONCLUSIONS}

The multivariate analyses indicate that depth and sediment type are the major overall determinants of community composition at the different sites. There is also an area of impoverished fauna and this is presumably caused by the seasonal development of stagnant waters below the pycnocline at the deeper stations. As hypothesised there is no indication of disturbed benthos near the natural oil seep even though PAHs occur at similarly high levels. This is evidenced in the dry season MDS where seep locations (viz. Stns 80, 81, 83 \& 73) cluster along with the larger mass of undisturbed stations. The clustering of these stations is even tighter in the wet season. This confirms the impression gained from visual examination of the faunal data matrix that species composition at the seep sites is not markedly different from the nearby heavily oiled nonseep stations. Closer inspection of the dry season biomass MDS (Fig. 2d) reveals that the seep stations separate in a line to the top of the diagram. This is because the vertical dimension in the MDS appears to be a biomass axis with stations having the highest average biomass per individual to the top. The crucial biological factor at the seep sites then is the increased biomass per individual. This may be due to the chronic nature of the hydrocarbon inputs, which when degraded by bacteria provide a constant abundant food source for the macrobenthos.

If this explanation is correct, why then doesn't the oil-adapted fauna colonise the oil refinery area? Explanations may lie in the episodic, synergistic and varied nature of contamination which occurs at this site. Inputs include not only crude oil and trace metals but occasionally also refined products and dispersants. Of the contaminant variables examined in the principal components analysis, lead levels, not PAHs, correlate best with the dry season abundance MDS. Dry season trace metal values at the most inshore refinery site were $\mathrm{Cd}=0.6 \mathrm{mg} \mathrm{l}^{-1}, \mathrm{Cu}=35.5 \mathrm{mg} \mathrm{l}^{-1}, \mathrm{~Pb}=$ 


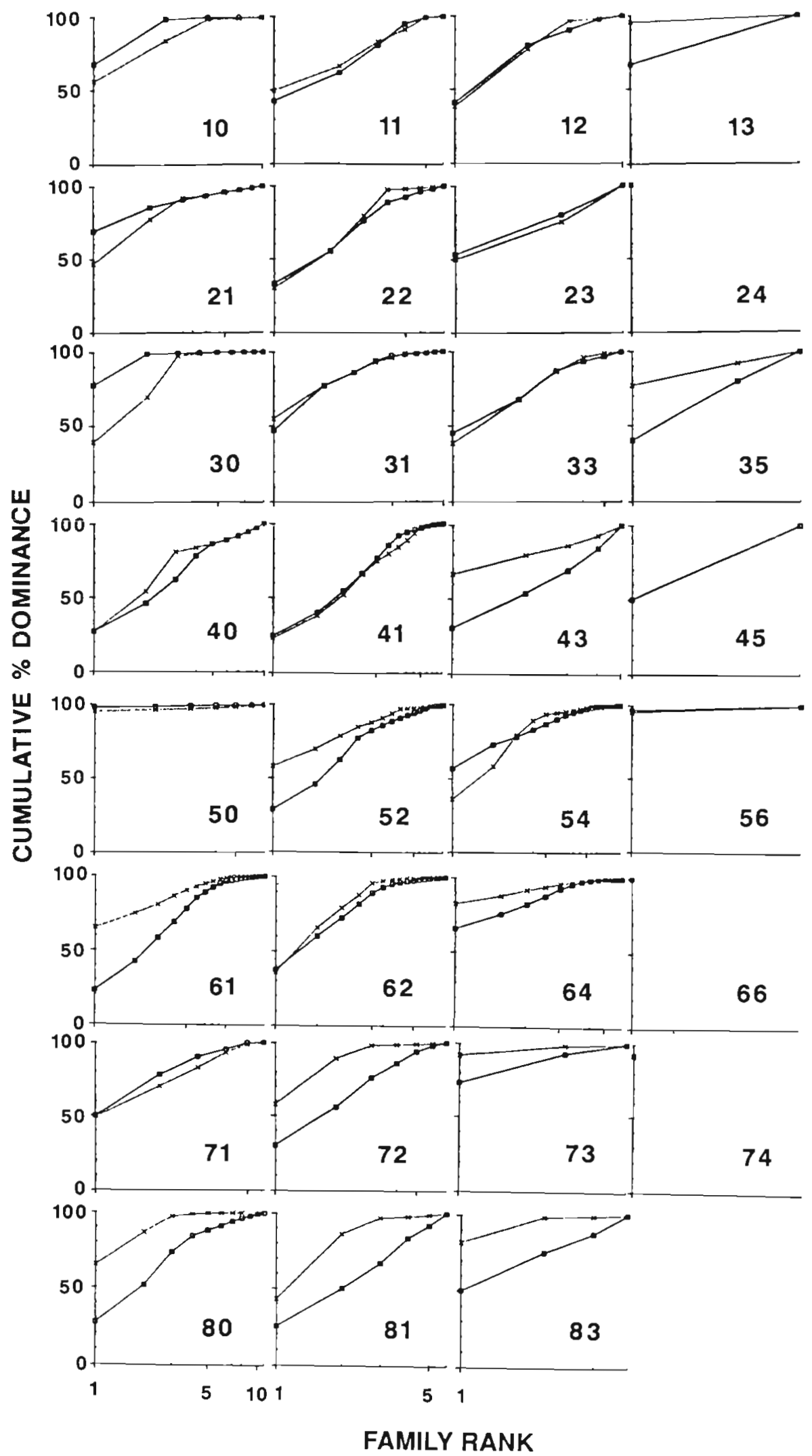

Fig. 7. ABC curves for dry season macrofauna families. ( $\mathbf{a})$ Abundance; (x) biomass 

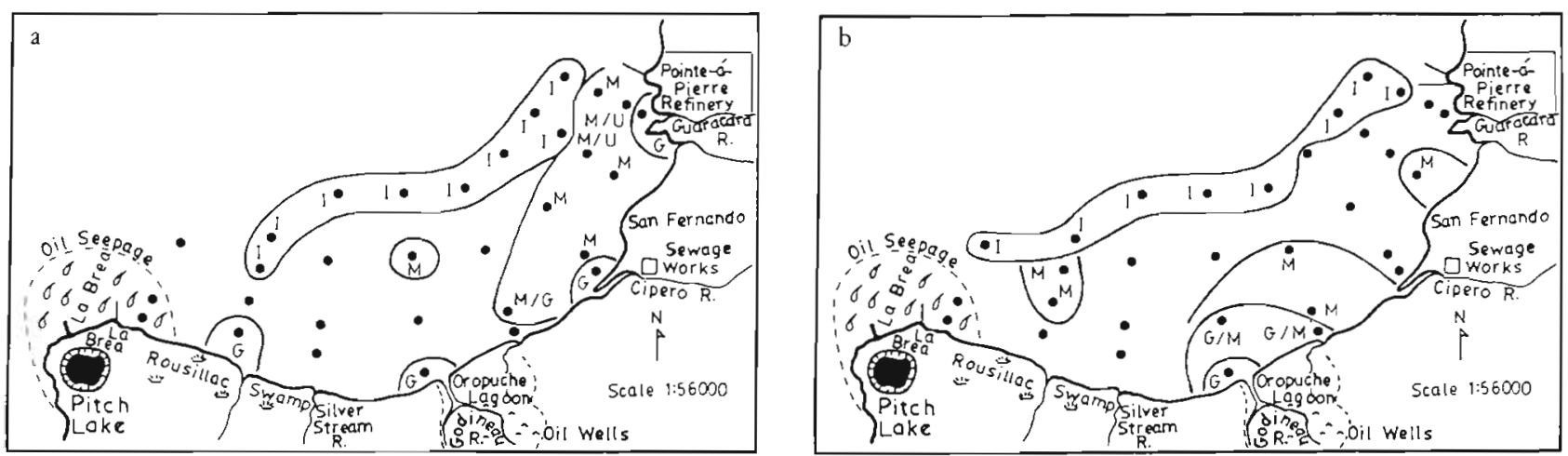

Fig. 8. As in Fig. 6 but curves based on macrofauna data aggregated into families
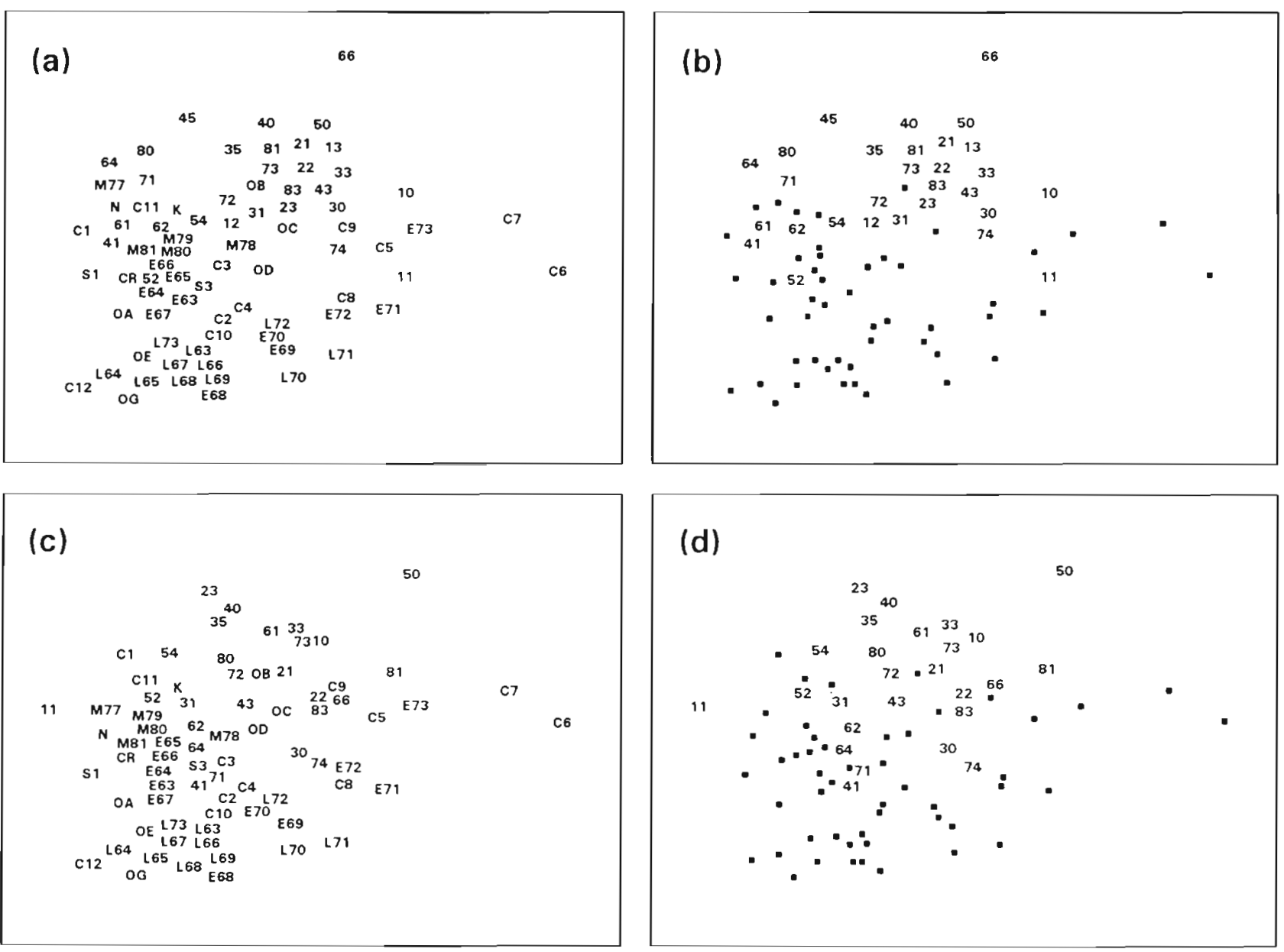

Fig. 9. MDS ordinations of standardised $W$ transformed phylum-level 'production' data from all sites combined with the NE Atlantic samples of Warwick \& Clarke (1993): (a) dry season; (b) dry season with only the Trinidad samples highlighted; (c) wet season; (d) wet season with only the Trinidad samples highlighted

$57.7 \mathrm{mg} \mathrm{l}^{-1}, \mathrm{Zn}=113.4 \mathrm{mg} \mathrm{l}^{-1}$ and $\mathrm{Hg}=0.6 \mathrm{mg} \mathrm{l}^{-1}$. Wet season results were only slightly lower. These levels are 2 to 20 times higher than at the oil seep sites and surrounding areas. The unstable conditions at the refinery site are suggested by the fact that during the wet season this station changed its $A B C$ classification to the undisturbed condition. This was mainly due to the biomass being dominated by a few very large indi- 
Table 1 Comparison between Trinidad and NE Atlantic samples in the proportion of production lestimated from $(B / A)^{073} \times A$ l attributable to each phylum, averaged over all samples. $\bar{\delta}_{i}$ is the contribution of the $i$ th phylum to the average Bray-Curtis dissimilarity $(\bar{\delta})$ between the 2 areas, also expressed as a cumulative percentage $\left(\sum \bar{\delta}_{i} \%\right)$. Phyla are listed in decreasing order of importance in contributions to $\bar{\delta}$

\begin{tabular}{|c|c|c|c|c|}
\hline Phylum & \multicolumn{2}{|c|}{$\begin{array}{l}\text { Avg production } \\
\text { Tropical Temperate }\end{array}$} & $\bar{\delta}_{1}$ & $\sum \bar{\delta}_{i} \%$ \\
\hline \multicolumn{5}{|c|}{$\begin{array}{l}\text { Dry season } \\
\text { Average dissimilarity, } \bar{\delta}=36.97\end{array}$} \\
\hline Crustacea & 13.25 & 3.58 & 7.61 & 20.58 \\
\hline Echinodermata & 3.77 & 10.24 & 7.29 & 40.31 \\
\hline Mollusca & 15.70 & 29.20 & 5.93 & 56.35 \\
\hline Nemertea & 1.38 & 1.14 & 4.69 & 69.04 \\
\hline Annelida & 65.55 & 54.08 & 2.86 & 76.79 \\
\hline Cnidaria & 0.00 & 0.35 & 2.28 & 82.95 \\
\hline Nematoda & 0.01 & 0.99 & 2.25 & 89.03 \\
\hline Sipuncula & 0.00 & 0.31 & 2.08 & 94.67 \\
\hline Hemichordata & 0.00 & 0.06 & 0.64 & 96.41 \\
\hline Chelicerata & 0.33 & 0.00 & 0.49 & 97.75 \\
\hline Priapulida & 0.00 & 0.03 & 0.26 & 98.45 \\
\hline Platyhelminthes & 0.00 & 0.02 & 0.26 & 99.14 \\
\hline Porifera & 0.02 & 0.00 & 0.15 & 99.55 \\
\hline Chordata & 0.00 & 0.00 & 0.10 & 99.83 \\
\hline \multicolumn{5}{|c|}{$\begin{array}{l}\text { Wet season } \\
\text { Average dissimilarity, } \bar{\delta}=36.81\end{array}$} \\
\hline Echinodermata & 6.12 & 10.24 & 7.70 & 20.91 \\
\hline Crustacea & 6.03 & 3.58 & 5.88 & 36.89 \\
\hline Mollusca & 21.20 & 29.20 & 5.78 & 52.60 \\
\hline Nemertea & 0.58 & 1.14 & 4.83 & 65.71 \\
\hline Annelida & 65.27 & 54.08 & 3.45 & 75.09 \\
\hline Cnidaria & 0.00 & 0.35 & 2.37 & 81.53 \\
\hline Nematoda & 0.00 & 0.99 & 2.27 & 87.71 \\
\hline Sipuncula & 0.00 & 0.31 & 2.14 & 93.51 \\
\hline Hemichordata & 0.00 & 0.06 & 0.66 & 95.31 \\
\hline Platyhelminthes & 0.01 & 0.02 & 0.46 & 96.55 \\
\hline Chelicerata & 0.02 & 0.00 & 0.44 & 97.74 \\
\hline Porifera & 0.77 & 0.00 & 0.39 & 98.81 \\
\hline Priapulida & 0.00 & 0.03 & 0.27 & 99.53 \\
\hline Chordata & 0.00 & 0.00 & 0.11 & 99.83 \\
\hline Phoronida & 0.00 & 0.00 & 0.06 & 100.00 \\
\hline
\end{tabular}

viduals of the polychaete Diopatra cuprea. This species also appeared at the oil seep site during the wet season. During the dry season, biomass at the oil seep stations was dominated by either of the polychaetes Loimia viridis or Notomastus hemipodus.

Re-plotting the $A B C$ curves from data aggregated to the family level produced a different classification for 5 of the stations. Firstly, Stns 22, 31, 33 \& 41 which were originally classified as undisturbed now showed various degrees of moderate disturbance. These stations are all on the periphery of inshore sites already established as grossly disturbed. The impression then is that the area of disturbance is extended. Conversely the outermost seep site, viz. Stn 83, was classified as moderate/undisturbed dur- ing the dry season but this status changes to 'undisturbed' after aggregation to the family level. This rating is more in line with the undisturbed nature of the surrounding stations.

Why does aggregation of data to the family level produce these effects, apparently increasing sensitivity to pollution and decreasing misclassification? One problem with the $\mathrm{ABC}$ curves is their overdependence on the single dominant species, for abundance and biomass (Clarke 1990), and it may be that aggregation to the family level reduces this effect. This finding supports the suggestion by Warwick (1988a, b) that analysis of higher taxonomic groups might more clearly reflect pollution gradients and be less affected by natural nuisance variables than species analyses. This is of considerable importance in determining the cost-effectiveness of a study like this. As much as $50 \%$ of the time consumed and cost incurred were associated with obtaining reliable species identifications beyond the family levcl. In particular, the polychaete and amphipod fauna of this region is so poorly known that this study was used as an aid to developing appropriate taxonomic literature (Uebelacker \& Johnson 1984, Barnard \& Agard 1986, Gobin 1990) so that future efforts would be made easier. We conclude, therefore, that in terms of the objectives of the study, no information would have been lost (indeed there appears to have been an information gain) and considerable time and costs would have been saved if the initial taxonomic identifications were done to no further than family level.

Comparison of the severity of community degradation using the phylum-level meta-analysis of Warwick \& Clarke (1993) seems to be compatible with the NE Atlantic data in terms of the locations of samples along the principal axis of the ordination. This suggests that the method may have some generality on a global rather than simply a regional scale. Warwick \& Clarke were unable to explain the separation of sites on the second (vertical) axis of the ordination, but in the case of the Trinidad sites this may conceivably be due to the estuarine character of the region which would not be conducive to echinoderms, which are osmoconformers.

Acknowledgements. We gratefully acknowledge the assistance of Paul Wolf (Barry Vittor \& Associates, Alabama) and Jerry L. Barnard (Smithsonian Institution-USNM, Washington, DC) for help with polychaete and amphipod species identifications respectively. Field and laboratory work were performed at the Institute of Marine Affairs, Trinidad. The Plymouth Marine Laboratory and the Department of Zoology, University of West Indies, provided data-processing support. Bob Clarke (Plymouth Marine Laboratory) provided helpful comments on an earlier draft of the manuscript. 


\section{LITERATURE CITED}

Agard, J. B. R., Boodoosingh, M., Gobin, J. (1988). Petroleum residues in surficial sediments from the Gulf of Paria, Trinidad. Mar. Pollut. Bull. 19: 231-233

Barnard, J. L., Agard, J. B. R. (1986). A new species of Ampelisca (Crustacea, Amphipoda) from Trinidad. Bull. mar. Sci. 39: 630-636

Clarke, K. R. (1988). Detecting change in benthic community structure. Proc. XIVth Int. Biometric Conf., Namur: Invited Papers. Societé Adolphe Quételet, Gembloux, p. 131-142

Clarke, K. R. (1990). Comparisons of dominance curves. J. exp. mar. Biol. Ecol. 138: 143-157

Clarke, K. R. (1993). Non-parametric multivariate analyses of changes in community structure. Aust. J. Ecol. (in press)

Clarke, K. R., Ainsworth, M. (1993). A method of linking multivariate community structure to environmental variables. Mar. Ecol. Prog. Ser. 92: 205-219

Clarke, K. R., Green, R. H. (1988). Statistical design and analysis for a 'biological effects' study. Mar. Ecol. Prog Ser. 46: 213-226

Ferraro, S. P., Cole, F. A. (1990). Taxonomic level and sample size sufficient for assessing pollution impacts on the Southern Califoria Bight macrobenthos. Mar. Ecol. Prog. Ser. $67: 251-262$

Field, J. G., Clarke, K. R., Warwick, R. M. (1982). A practical strategy for analysing multispecies distribution patterns. Mar. Ecol. Prog. Ser. 8: 37-52

Geyer, R. A., Giammona, C. P. (1980). Naturally occurring hydrocarbons in the Gulf of Mexico and Caribbean Sea. In: Geyer, R. A. (ed.) Marine environmental pollution, Vol. 1. Elsevier, Amsterdam, p. 37-106

Gobin, J. (1990). A checklist of marine polychaetous annelids (Polychaeta) for the Gulf of Paria, Trinidad, West Indies. Caribb. Mar. Stud. 1: 37-47

Government of Trinidad and Tobago (1984). National Oil Spill Clean-up Plan for Trinidad and Tobago. Ministry of Energy and Natural Resources, Port of Spain

This article was submitted to the editor
Gray, J. S., Aschan, M., Carr, M. R., Clarke, K. R., Green, R. H., Pearson, T. H., Rosenberg, R., Warwick, R. M. (1988). Analysis of community attributes of the benthic macrofauna of Frierfjord/Langesundfjord and in a mesocosm experiment. Mar. Ecol. Prog. Ser. 46: 151-165

International Oceanographic Commission (1982). The determination of petroleum hydrocarbons in sediments. Manuals and guides, No. 11 UNESCO, Paris

Kruskal, J. B., Wish, M. (1978). Multidimensional scaling Sage Publications, Beverley Hills

Pearson, T. H. (1987). The benthic ecology of an accumulating sludge disposal ground. In: Capuzzo, J., Kester, D. (eds.) Biological processes and wastes in the ocean. R. E. Krieger, Melbourne, FL, p. 195-200

Uebelacker, J. M., Johnson, P. G. (eds.) (1984). Taxonomic guide to polychaetes of the northern Gulf of Mexico, Vols. 1-7. Barry A. Vittor \& Associates, Mobile, AL

Warwick, R. M. (1986). A new method for detecting pollution effects on marine macrobenthic communities. Mar Biol. 92: $557-562$

Warwick, R. M. (1988a). Analysis of community attributes of the macrobenthos of Frierfjord/Langesundfjord at taxonomic levels higher than species. Mar. Ecol. Prog. Ser 46: $167-170$

Warwick, R. M. (1988b). The level of taxonomic discrimination required to detect pollution effects on marine benthic communities. Mar. Pollut. Bull. 19: 259-268

Warwick, R. M. (1988c). Effects on community structure of a pollution gradient-summary. Mar. Ecol. Prog. Ser. 46: $207-211$

Warwick, R. M., Clarke, K. R. (1993). Comparing the severity of disturbance: a meta-analysis of marine macrobenthic community data. Mar. Ecol. Prog. Ser. 92: 221-231

Wilson, R. D., Monaghan, P. H., Osanik, A., Price, L. C., Rogers, M. A. (1974). Natural marine oil seepage. Science 184(4139): $857-865$

ZoBell, C. E., Feltham, C. B. (1938). Bacteria as food for certain marine invertebrates. J. mar. Res. 1. 312-328

Manuscript first received: March 3, 1992

Revised version accepted: November 30, 1992 